Jurnal Riset Manajemen dan Akuntansi

Volume 02 - No. 01, April 2015

\title{
ANALISIS PENGENDALIAN INTERN PIUTANG USAHA PADA KOPERASI PEMBANGUNAN USAHA SUMBAR
}

\author{
Dewi Zulvia \\ Sekolah Tinggi Ilmu Ekonomi “KBP” Padang
}

\begin{abstract}
The purpose of this study was to determine the internal control accounts receivable at West Sumatra Business Development Cooperative (KOPUS) have been effective or not .. This study is a survey, because this study only make observations and then analyze the data. This type of data is the questionnaire. The data analysis technique is descriptive qualitative and quantitative undertaken to draw conclusions. This questionnaire is used to determine the internal control accounts receivable at West Sumatra Business Development Cooperative (KOPUS). From the results of the questionnaire, it can be of value, which is divided into categories strongly agree, agree, undecided, disagree and strongly disagree. The results of this study indicate that, overall, internal control of accounts receivable at West Sumatra Business Development Cooperative (KOPUS) is effective, where the management company has to apply the basic concepts and principles of internal control.
\end{abstract}

Keyword: Internal Control, Accounts Receivable.

\section{PENDAHULUAN}

\section{Latar Belakang Masalah}

Koperasi merupakan salah satu bentuk organisasi berbadan hukum yang bergerak dibidang perekonomian. Pembangunan koperasi di Indonesia merupakan merupakan bagian dari usaha nasional secara keseluruhan dan mendapatkan perhatian dari pemerintah. Koperasi bertujuan untuk memajukan kesejahteraan anggota pada khususnya dan masyarakat pada umumnya.

Menurut Undang-undang Nomor. 17 Tahun 2012 pasal 1 ayat 1 revisi dari Undang-undang 25 tahun 1992 pasal 1 ayat 1 "Koperasi adalah badan usaha yang didirikan orang perorangan atau berbadan hukum yang dengan pemisahan kekayaan para anggotanya sebagai modal untuk menjalankan usahanya yang memenuhi aspirasi dan kebutuhan bersama di bidang ekonomi, sosial, dan budaya sesuai dengan prinsip Koperasi”.

Kegiatan koperasi berorientasi pada usaha yang berkaitan langsung dengan kepentingan anggota untuk meningkatkan usahanya dan kesejahteraan anggotanya. Untuk melakukan kegiatannya koperasi memerlukan modal. Modal koperasi terdiri dari modal sendiri (simpanan pokok dan simpanan wajib), modal cadangan, dan modal sumbangan (hibah), serta modal penyertaan.

Kegiatan simpan pinjam koperasi dapat meningkatkan permodalan pada koperasi itu sendiri. Kegiatan simpan pinjam adalah kegiatan untuk menghimpun dan menyalurkan dana dari anggota yang bersangkutan. Koperasi Pembangunan Usaha Sumbar adalah salah satu Koperasi Simpan Pinjam berbadan hukum yang ada di Kota Padang yang menyelenggarakan usaha simpan pinjam dan usaha lainnya. Pada kegiatan simpan pinjam diperuntukkan bagi anggota Koperasi dan Masyarakat Umum.

Usaha Simpan Pinjam merupakan unit usaha yang memiliki tingkat intensitas yang tinggi, dan dalam 
pemberian pinjaman perlu adanya suatu peraturan yang tepat dan pengendalian intern terhadap piutang yang sangat penting untuk diterapkan. Dengan adanya hal tersebut maka dapat membantu manajer koperasi mengambil suatu keputusan tentang kelayakan pemberian pinjaman kepada anggotanya dan masyarakat umum.

Mengingat Piutang pinjaman merupakan modal kerja yang diharapkan dapat memperoleh tambahan penghasilan dan laba, maka kehadiran piutang pinjaman dapat menimbulkan suatu resiko kerugian yang cukup besar untuk koperasi. Dalam hal ini tentunya diperlukan pengendalian intern terhadap piutang. Pengendalian intern merupakan salah satu cara yang digunakan dalam mengantisipasi kecurangan yang merugikan Koperasi.

Pengendalian intern merupakan suatu rencana organisasi dan metode bisnis yang digunakan untuk meningkatkan efektivitas dan efisiensi, menjaga aset, memberikan informasi yang akurat, mendorong dipatuhinya kebijakan manajemen yang telah ditetapkan.

Berdasarkan uraian yang telah diuraikan diatas, penulis tertarik untuk melakukan penelitian dengan judul : "Analisis Pengendalian Intern Piutang Usaha Pada Koperasi Pembangunan Usaha Sumbar".

\section{LANDASAN TEORI}

Konsep Pengendalian Intern

Pengertian Pengendalian Intern

Pengendalian intern merupakan kegiatan yang sangat penting sekali dalam pencapaian tujuan usaha. Demikian pula dunia usaha mempunyai perhatian yang makin meningkat terhadap pengendalian intern. Sawyers (2005: 58) mendefenisikan pengendalian intern "suatu proses yang dipengaruhi oleh aktivitas dewan komisaris, manajemen atau pegawai lainnya yang didesain untuk memberikan keyakinan yang wajar tentang pencapaian tiga golongan tujuan berikut ini : a. kehandalan pelaporan keuangan, b. efektivitas dan efesiensi operasi, c. kepatuhan terhadap hukum dan peraturan yang berlaku “.

\section{Prinsip Dasar Pengendalian Intern}

Ada beberapa asumsi dasar yang perlu dipahami mengenai pengendalian intern bagi suatu entitas organisasi atau perusahaan.

Menurut Sanyoto (2007 : 256) konsep dasar yang mendasari telaah atas struktur pengendalian intern yaitu :

a. Sistem pengendalian intern merupakan management responsibility. Bahwa sesungguhnya yang paling berkepentingan terhadap sistem pengendalian intern suatu entitas organisasi / perusahaan adalah manajemen (lebih tegasnya lagi ialah top management / direksi), karena dengan sistem pengendalian intern yang baik itulah top management dapat mengharapkan kebijakannya dipatuhi, aktiva atau harta perusahaan dilindungi, dan penyelenggaraan pencatatan berjalan baik.

b. Top management bertanggungjawab menyususn sistem pengendalian intern, tentu saja dilaksanakan oleh para stafnya. Dalam penyususnan team yang akan ditugaskan untuk merancang sistem pengendalian intern, harus dipilih anggotanya dari para ahli / kompeten, termasuk yang berkaitan dengan teknologi informasi (mengingat pada saat ini sistem lazimnya didesain dengan berbasis teknologi informasi).

c. Sistem pengendalian intern seharusnya bersifat generic, mendasar, dan dapat diterapkan pada tiap perusahaan pada 
umumnya (tidak boleh jika hanya berlaku untuk suatu perusahaan tertentu saja, melainkan harus ada hal-hal yang brsifat dasar yang berlaku umum).

d. Sifat sistem pengendalian intern adalah reasonable assurance, artinya tingkat rancangan yang kita desain adalah yang paling optimal. Sistem pengendalian yang paling baik ialah bukan yang paling maksimal, apalagi harus dipertimbangkan keseimbangan cost benefit-nya.

e. Sistem pengendalian intern mempunyai keterbatasanketerbatasan atau constraints, misalnya adalah sebaik-baiknya kontrol tetapi kalau para pegawai yang melaksanakannya tidak cakap, atau kolusi, maka tujuan pengendalian itu mungkin tidak tercapai.

f. Sistem pengendalian intern harus selalu dan terus menerus dievaluasi, diperbaiki, disesuaikan dengan perkembangan kondisi dan teknologi.

\section{Tujuan Pengendalian Intern}

Tujuan pengendalian intern menurut COSO (Committee of Sponsoring Organizations) (Sanyoto, 2007 : 257)

a. Untuk menyediakan data yang dapat dipercaya, termasuk :

1) Kelengkapan, input/ proses / output

2) Akurasi : input / proses / output

3) Keunikan

4) Kewajaran

5) Kesalahan yang terdeteksi

b. Untuk mendorong kepatuhan terhadap kebijakan akuntansi yang ditentukan, termasuk :

1) Ketepatan waktu

2) Penilaian, perhitungan, dan ringkasan

3) Klasifikasi c. Untuk menjaga aset dan catatan, termasuk :

1) Transaksi resmi

2) Distribusi output

3) Validitas, tidak ada data nonvalid diproses

4) Keamanan data dan catatan

\section{Keterbatasan Pengendalian Intern}

Perlu diingat bahwa sistem pengendalian intern yang terbaik adalah bukan struktur pengendalian yang seketat mungkin secara maksimal, sistem pengendalian intern juga mempunyai keterbatasan-keterbatasan. Kelemahan atau keterbatasan yang melekat pada sistem pengendalian intern menurut Sanyoto (2007 : 253) adalah sebagai berikut :

a. Persekongkolan (kolusi)

Pengendalian intern mengusahakan agar persekongkolan dapat dihindari sejauh mungkin, misalnya dengan mengharuskan giliran bertugas, larangan dalam menjalankan tugastugas yang bertentangan oleh mereka yang mempunyai hubungan kekeluargaan, keharusan mengambil cuti dan seterusnya. Akan tetapi pengendalian intern tidak dapat menjamin bahwa persekongkolan tidak terjadi.

b. Perubahan

Struktur pengendalian intern pada suatu organisasi harus selalu diperbaharui sesuai dengan perkembangan kondisi dan teknologi.

c. Kelemahan manusia

Banyak kebobolan terjadi pada sistem pengendalian intern yang secara teoritis sudah baik. Hal tersebut dapat terjadi karena lemahnya pelaksanaan yang dilakukan oleh personil yang bersangkutan. Oleh karena, itu personil yang paham dan kompeten untuk menjalankannya merupakan salah satu unsur terpenting dalam pengendalian intern.

d. Azas biaya manfaat 


$\begin{array}{llr}\text { Pengendalian } & \text { juga } & \text { harus } \\ \text { mempertimbangkan } & \text { biaya } & \text { dan } \\ \text { kegunaannya. } & \text { Biaya } & \text { untuk } \\ \text { mengendalikan hal-hal tertentu } & \text { han } & \text { hangin melebihi kegunaannya, atau } \\ \text { mungkin } & \text { manfaat tidak sebanding dengan biaya } \\ \text { yang dikeluarkan } & \text { (cost-benefit } \\ \text { analysis). }\end{array}$

\section{METODE PENELITIAN}

Objek Penelitian

Objek penelitian dalam penulisan skripsi ini, yang menjadi objek penelitian adalah Koperasi Pembangunan Usaha Sumbar (KOPUS) yang beralamat di jalan H. Agus Salim no. 3C Padang (Komplek Sumatera Plaza).

\section{Jenis Data}

Jenis data yang dikumpulkan dalam penelitian ini adalah data primer dan data sekunder.

1. Data primer, berupa data yang diperoleh langsung dari perusahaan melalui wawancara dan kuesioner tentang pengendalian intern terhadap piutang usaha dengan manajer, dan karyawan yang terkait langsung dengan objek yang diteliti, dan kegiatan observasi yang kemudian akan diolah penulis.

2. Data sekunder, berupa data yang dikumpulkan melalui catatan dan dokumen resmi perusahaan dan data yang telah diolah seperti sejarah singkat perusahaan, memo internal, struktur organisasi, dan dokumen lainnya.

\section{Teknik Pengumpulan Data}

Teknik yang digunakan dalam mengumpulkan data adalah studi dokumentasi, teknik wawancara, dan teknik observasi.

1. Studi dokumentasi, yakni melalui pencatatn dan fotocopy data yang diperlukan. Seperti pencatatan hasil wawancara, fotocopy memo internal perusahaan, dsb.
2. Teknik wawancara, yakni dengan melakukan tanya jawab secara langsung dengan pihak-pihak yang terkait dengan objek penelitian.

3. Teknik observasi, yakni dengan melakukan pengamatan terhadap kegiatan atau pun prosedur kerja yang berhubungan dengan objek penelitian.

\section{Jenis Penelitian}

Jenis penelitian yang dilakukan adalah penelitian berbentuk deskriptif. Penelitian berbentuk deskriptif adalah penelitian dengan pendekatan spesifik untuk mengungkapkan fakta dalam hubungan sebab akibat, bersifat eksploratif untuk mencari keterangan apa sebab terjadinya masalah, bagaimana memecahkannya. Akan tetapi sifatnya hanya mendalam pada satu unit peristiwa.

\section{Metode Analisis Data}

Analisis data yang dilakukan dalam penelitian ini adalah dengan metode deskriptif. Metode deskriptif adalah metode analisis dengan terlebih dahulu mengumpulkan data yang ada kemudian diklarifikasi, dianalisis, selanjutnya diinterpretasikan sehingga dapat memberikan gambaran yang jelas mengenai keadaan yang diteliti.

\section{Sistem Pemberian Pinjaman Koperasi Pembangunan Usaha Sumbar}

Sistem pemberian pinjaman yang dilaksanakan oleh Koperasi Pembangunan Usaha Sumbar (KOPUS) mengacu pada tujuan pinjaman, dalam arti memenuhi prinsip aman, terarah, produktif, dan jaminan dari nasabah bahwa uang yang diberikan akan kembali dengan selamat. Hal ini berarti bahwa prosedur yang dilaksanakan harus benar-benar dipenuhi untuk menjaga atau meminimalkan resiko yang terjadi.

Sistem pemberian pinjaman pada Koperasi Pembangunan Usaha Sumbar 
(KOPUS), dapat dijelaskan berdasarkan prosedur pemberian pinjaman berikut :

1. Permohonan Pinjaman

Permohonan disebut juga sebagai tahap persiapan yang merupakan proses awal dari aktivitas pemberian pinjaman, dalam prosedur ini, selain mengisi formulir permohonan, pemohon harus memenuhi segala persyaratan yang telah ditentukan agar permohonan pinjaman dapat diproses. Persyaratan yang dimaksud adalah sebagai berikut :

a. Identitas/ data diri calon peminjam, terdiri dari :

- Fotocopy KTP

- Kartu Keluarga

- Pas Foto

- Slip Gaji (Bagi Karyawan)

b. Keberadaan agunan, bisa berupa :

- Sertifikat hak milik

- Surat-surat berharga lainnya

- BPKB sepeda motor/ mobil

Ketika segala persyaratan tersebut telah dimiliki, calon debitur kemudian diminta untuk mengisi sendiri formulir permohonan lalu mengumpulkannya ke petugas dengan melampirkan salinan-salinan persyaratan tersebut. Setelah itu, petugas akan mencatat permohonan tersebut ke dalam register.

2. Analisa Pinjaman

Tujuan utama dari analisis pinjaman adalah untuk memperoleh keyakinan apakah calon debitur mempunyai kemauan, kemampuan, serta dapat dipercaya dan bertanggungjawab untuk membayar kembali pinjaman yang telah diterima dengan tepat waktu.

Pada tahap analisis ini dilakukan analisis terhadap formulir permohonan, diantaranya kelengkapan, legalitas, dan kebenaran dokumen diteliti. Penilaian atas permohonan ini disusun setelah semua data terkumpul dengan lengkapdan telah diadakan berbagai pengecekan sesaui dengan ketentuan yang berlaku.

Pada dasarnya analisa yang digunakan oleh Koperasi Pembangunan Usaha Sumbar (KOPUS) menggunakan prinsip 5C, yaitu :

a. Character/Watak

Analisa Character dilakukan karena sebelum pinjaman disalurkan perlu diyakini benar apakah debitur mempunyai watak atau sifat yang baik, dalam arti tidak membiasakan diri bengingkar janji dan selalu berusaha untuk memenuhi janji. Untuk memperoleh gambaran tersebut maka Koperasi Pembangunan Usaha Sumbar (KOPUS) meneliti data-data sebagai berikut :

- Riwayat Hidup

- Reputasi Pemohon di masyarakat dan lingkungan kerja.

b. Capacity/ Kemampuan

Untuk mendapatkan informasi yang akurat mengenai kemampuan calon nasabah dalam menjalankan usahanya maka dilakukan analisa mengenai kegiatan usaha debitur, meliputi :

- Kepemilikan tempat dan lokasi usaha

- Tempat tinggal tetap debitur

- Jenis usaha dan besar kecilnya usaha

- Prospek dari jenis usaha debitur

\section{c. Capital/ Modal}

Dalam hal ini pihak Koperasi Pembangunan Usaha Sumbar (KOPUS) akan melihat berapa modal yang dimiliki oleh debitur, hal ini dapat dilihat dari jenis usaha debitur. 
d. Collateral/Jaminan

Jaminan/ agunan ini dapat berupa jaminan-jaminan material maupun surat berharga yang disiapkan oleh nasabah untuk menanggung pembayaran kembali pinjaman sesuai dengan yang dijanjikan.

e. Condition of Economy/ Kondisi Ekonomi

$\begin{array}{lr}\text { Pihak } & \text { koperasi } \\ \text { mempertimbangkan } & \text { sejauh } \\ \text { mana kondisi ekonomi } & \\ \text { berpengaruh terhadap para } \\ \text { debitur. Misalnya kenaikan } \\ \text { harga BBM, dll. }\end{array}$

3. Keputusan Pinjaman

Keputusan pinjaman meliputi langkah akhir dari hasil penilaian pinjaman, apakah permohonan pinjaman akan ditolak atau disetujui untuk diberikan. Sebelum memutuskan untuk menyetujui atau menolak permohonan pinjaman, manajer terlebih dahulu memeriksa hasil analisis pinjaman, dan meneliti kelengkapan persyaratan yang diberikan. Jika sudah disetujui, maka manajer akan menyerahkan dokumen dan perintah pencairan pada bagian administrasi.

\section{Perjanjian}

Setelah permohonan disetujui, maka dibuat surat perjanjian oleh bagian administrasi.

Adapun isi dari surat perjanjian meliputi :

1. Informasi mengenai pinjaman

2. Surat penyerahan milik secara kepercayaan

3. Surat pernyataaan kepemilikan barang

4. Surat penyerahan dan kuasa menjual

Surat perjanjian tersebut harus ditandatangani oleh manajer dan peminjam. Surat perjanjian lalu diarsip oleh administrasi.

5. Pencairan
Setelah ketentuan-ketentuan pinjaman dipenuhi, tahap terakhir dari prosedur pinjaman adalah pencairan. Prosedur penairan sebagai berikut :

1. Administrasi :

a. Menyerahkan slip pencairan kepada kasir

b. Menyimpan disposisi pencairan dan kelengkapan pinjmaan

c. Membuat kartu piutang/ pinjaman

d. Mencatat slip pencairan pinjaman pada buku mutasi.

2. Kasir

a. Memeriksa persetujuan (ACC) pada slip pencairan

b. Menghitung uang tunai dan menyerahkan pada debitur bersama bukti penerimaan jaminan

c. Mencatat pada buku mutasi harian kas

Pengendalian Intern atas Piutang Usaha pada Koperasi Pembangunan Usaha Sumbar (KOPUS)

Pada dasarnya pengendalian internal yang memadai akan membantu manajemen dalam meningkatkan efektivitas dan efisiensi kegiatan operasional perusahaan, keandalan laporan keuangan, dan meningkatkan kepatuhan terhadap hukum dan peraturan-peraturan.

Pengendalian internal yang diterapakn pada Koperasi Pembangunan Usaha Sumbar (KOPUS) memuat seluruh unsur-unsur pokok pengendalian intern.

\section{Lingkungan Pengendalian}

Dalam lingkungan pengendalian, Koperasi Pembangunan Usaha Sumbar (KOPUS) mempunyai komitmen bahwa pengendalian intern merupakan hal yang penting. Untuk mewujudkan pengendalian intern tersebut maka diterapkan unsur-unsur :

a. Integritas dan Nilai Etika 
Koperasi menerapkan integritas dan etika pada seluruh karyawannya. Hal ini dapat dilihat dengan adanya peraturan-peraturan yang ditetapkan oleh manajemen berupa tata cara kepegawaian mengenai etika dan perilaku. Aturanaturan tersebut kemudian dikomunikasikan kepada setiap karyawan yang harus dilaksanakan oleh setiap karyawan. Apabila ada karyawan yang tidak melaksanakan aturan-aturan yang telah ditetapkan tersebut, maka kepada karyawan tersebut akan dikenakan sanksi.sanksi yang dikenakan dapat berupa teguran secara lisan, teguran secara tertulis, atau surat peringatan.

Selain aturan-aturan, Koperasi juga menetapkan kriteria berpakaian untuk para karyawan, yaitu :

- Dari hari senin s/d sabtu memakai seragam yang telah ditentukan.

- Setiap hari karyawan maupun karyawati menggunakan sepatu.

Melalui aturan tersebut, manajemen telah berusaha mengurangi penyimpangan yang mengakibatkan karyawan bertindak tidak jujur, dalam melakukan transaksi piutang/ pinjaman, integritas dan nilai etika karyawannya cukup baik. Hal ini terlihat dari kejujuran karyawan dalam melaksanakan kebijakan pinjaman dengan benar sehingga pinjaman yang diberikan dapat kembali dalam waktu yang telah disepakati bersama.

b. Komitmen terhadap Kompetensi

Komitmen terhadap kompetensi Koperasi sudah cukup baik, hal ini dapat dilihat dari setiap karyawan yang ditempatkan sesuai dengan pendidikan, pengetahuan, keterampilan, dan pengalaman.

Koperasi Pembangunan Usaha Sumbar (KOPUS) juga menetapkan spesifikasi yang jelas mengenai uraian pekerjaan dan latar belakang pendidikan juga keterampilan yang dibutuhkan oleh seorang karyawan untuk menempati posisi tertentu.

c. Dewan direksi dan komite audit

Pada Koperasi Pembangunan Usaha Sumbar (KOPUS) telah terdapat audit internal yang dilakukan oleh Badan Pengawas, tetapi tidak secara keseluruhan. Adapun hal-hal yang dilakukan oleh Badan Pengawas sesuai dengan fungsinya adalah :

- Mengawas pelaksanaan dan kegiatan pengurus sesuai dengan Anggaran Dasar serta keputusan anggota

- Mengawasi pelaksanaan rencana anggaran dan belanja serta realisasi penerimaan koperasi sesuai dengan amanah RAT

- Memeriksa dan meneliti teknik pembukuan dan administrasi yang berhubungan dengan organisasi usaha

- Melakukan koreksi bagi kekeliruan yang dijumpai dalam pembukuan dan administrasi

- Melaporkan pada rapat anggota.

d. Struktur Organisasi

Koperasi Pembangunan Usaha Sumbar (KOPUS) memiliki struktur organisasi bebentuk organisasi lini dan staff yang mencerminkan garis wewenang dan tanggungjawab yang ada dalam pencapaian tujuan koperasi.

e. Pembagian Wewenang dan Tanggung Jawab

Seperti yang terlihat dalam struktur organisasi Koperasi Pembangunan Usaha Sumbar (KOPUS), terdapat pelimpahan wewnang dan tanggungjawab yang jelas yang dapat dilihat pada struktur organisasi.

f. Kesadaran Pengendalian

Manajemen

sebagai penanggungjawab selalu concern terhadap kemungkinan adanya penyimpangan. Sedini mungkin manajemen akan menerapkan sistem pengendalian untuk menghindari 
penyimpangan serta terbuka dengan laporan pengawas guna meningkatkan efektivitas.

\section{Aktivitas Pengendalian}

Aktivitas pengendalian dibuat untuk memberikan keyakinan bahwa petunjuk yang dibuat oleh manajemen telah dilaksanakan. Unsure pengendalian intern piutang usaha yang menyangkut aktivitas pengendalian pada Koperasi Pembangunan Usaha Sumbar (KOPUS) adalah :

a. Pemisahan Tugas yang Cukup Struktur organisasi menunjukkan adanya pemisahan fungsi khususnya bagian-bagian yang terkait dengan pengendalian intern piutang usaha serta sistem pemberian pinjaman.

b. Dokumen dan Catatan yang Memadai

Dokumen dan catatan merupakan objek dimana setiap transaksi di-entry dan dikhtisarkan. Setiap transaksi yang terjadi dicatat pada dokumennya masing-masing. Bukti-bukti transaksi yang berupa slip maupun bukti lainnya dicatat dan diarsipkan oleh bagian-bagian yang bertanggungjawab seperti kasir, administrasi dan accounting.

c. Pengendalian Fisik atas Piutang dan Catatan

Untuk memenuhi pengendalian fisik atas piutang dan catatan, setiap bagian mengadakan lemari arsip untuk menyimpan catatan peting. Selain itu koperasi secara berkala melakukan pemantauan dan penilaian perkembangan pinjaman yang disalurkan. Ini dilakukan dengan memeriksa dokumendokumen dan mewajibkan melaporkan tingkat kolektibilitas piutang usaha dalam laporan intern.

d. Performance Review

Koperasi Pembangunan Usaha Sumbar secara berkala melakukan evaluasi terhadap karyawannya.
Evaluasi dilakukan setiap enam bulan sekali. Ini dilakukan untuk meningkatkan kinerja para karyawannya. Karyawan yang berprestasi akan diberikan penghargaan berupa materi.

\section{Informasi dan Komunikasi}

Informasi pada Koperasi

Pembangunan Usaha Sumbar (KOPUS) mulai dari entry data-data yang berhubungan dengan debitur, pokok pinjaman, tanggal pinjaman dan laporan. Informasi-informasi tersebut diolah dan dijadikan sebagai alat pengambil keputusan oleh manajer dan dikomunikasikan kepada personil baik secara formal maupun informal.

\section{Pemantauan}

Manajemen

Koperasi

Pembangunan Usaha Sumbar (KOPUS) telah menggariskan tanggung jawab kepada masing-masing bagian secara jelas. Kelancaran pinjaman atau piutang usaha menjadi tanggung jawab bagi tiap-tiap bagian yang membidangi piutang usaha. Karena memang antara bagian yang satu dengan bagian lainnya saling berkaitan.

Pemantauan yang dilakukan oleh Koperasi Pembangunan Usaha Sumbar (KOPUS) adalah untuk mendeteksi secara dini kemungkinan adanya penyimpangan yang telah ditetapkan sebelumnya dalam perjanjian kredit baik oleh koperasi maupun oleh peminjam.

Penyimpangan tersebut merupakan faktor resiko yang dapat merugikan Koperasi maupun peminjam. Koperasi Pembangunan Usaha Sumbar (KOPUS) secara berkesinambungan melakukan pengawasan dan evaluasi terhadap semua kegiatan operasi koperasi, dengan tujuan mengetahui kekuatan dan kelemahan yang ada dalam koperasi, sehingga dapat diupayakan pengendalian internal yang lebih baik. 


\section{Analisis Tingkat Pengendalian Intern Piutang Usaha}

Berdasarkan penelitian yang dilakukan penulis terhadap prosedur kerja, mulai dari sistem pemberian pinjaman sampai pelunasan piutang usaha pada Koperasi Pembangunan Usaha Sumbar (KOPUS) diketahui bahwa manajemen memberikan perhatian yang baik terhadap pengendalian intern piutang usaha, baik dari segi pengelolaan hingga pengawasan piutang usaha tersebut.

Lingkungan pengendalian terhadap piutang usaha pada Koperasi Pembangunan Usaha Sumbar (KOPUS) sudah berjalan dengan baik atau telah memadai, hal ini dapat ditandai dengan indepedensi badan pengawas, dan perusahaan memiliki struktur organisasi yang jelas menerangkan pembagian tugas, wewenang, dan tanggung jawab begitu pula dengan konsep pengendalian intern yang diterapkan sudah berjalan dengan baik pula.

Aktivitas penetuan resiko terhadap piutang usaha pada Koperasi Pembangunan Usaha Sumbar (KOPUS) telah memadai dan sudah efektif, hal ini ditandai dengan adanya Koperasi Pembangunan Usaha Sumbar (KOPUS) melakukan penaksiran risiko atas kemungkinan salah saji laporan keuangan yang meliputi kejadian-kejadian internal dan eksternal yang timbul karena perubahan dalam lingkungan operasional atas pemberian pinjaman dalam perusahaan. Manajemen juga mengasuransikan setiap personil yang melakukan penagihan piutang, seperti asuransi kecelakaan, asuransi pencurian dsb.

Aktivitas pengendalian terhadap piutang usaha telah efektif, hal ini ditandai dengan adanya kebijakan dan prosedur yang dibuat untuk memastikan bahwa arahan pimpinan dilaksanakan dengan baik. Aktivitas pengendalian yang dilakukan oleh Koperasi Pembangunan Usaha Sumbar (KOPUS) dalam kaitannya dengan piutang usaha adalah :

- Pemberian pinjaman memberikan otorisasi dari pejabat yang berwenang.

- Bukti pemberian pinjaman terdiri dari beberapa rangkap dan didistribusikan kepada bagian yang berbeda guna kepentingan pengawasan internal.

- Saldo pinjaman yang ada dapat dijamin perlindungannya dari kemungkinan besar penipuan.

- Pencatatan dalam jurnal pemberian pinjaman didasarkan pada bukti pinjaman masuk yang telah diotorisasi oleh pejabat yang berwenang dan dilampiri oleh dokumen lengkap.

- Koperasi dilengkapi dengan alat-alat yang dapat mencegah tindakan penipuan terhadap aktivitas pinjaman yang dilaksanakan.

- Pencatatan ke dalam kartu piutang dan ke dalam jurnal pendapatan, jurnal penerimaan kas, dan jurnal umum diotorisasi oleh fungsi akuntansi dengan cara memberikan tanda tangan pada dokumen sumber (faktur, bukti kas masuk, dan memo kredit).

- Pemegang kartu piutang tidak merangkap sebagai penerima kas (Kasir).

- Fungsi penagihan hanya dilakukan oleh satu bagian saja, sehingga tidak ada fungsi lain memiliki lebih dari satu 
wewenang yakni dalam melakukan penagihan.

- Dokumen pemberian pinjaman telah bernomor urut tercetak.

Informasi dan Komunikasi terhadap piutang usaha sudah efektif, hal ini ditandai dengan pengendalian internal dalam hal informasi dan komunikasi pada Koperasi Pembangunan Usaha Sumbar (KOPUS) yang meliputi :

- Manajemen selalu mengkomunikasikan segala informasi terbaru dan kebijakan lainnya seputar piutang usaha kepada karyawan yang terlibat langsung setiap saat.

- Manajemen memperoleh informasi mengenai total pinjaman debitur atau total piutang usaha untuk setiap bulannya.

- Terdapat sistem informasi yang mencakup metode-metode dan catatan-catatan untuk menunjukkan dan mencatat semua transaksi pemberian pinjaman yang sah.

- Terdapat sistem informasi yang mencakup metode-metode catatan untuk menggambarkan dengan dasar yang tepat transaksi-transaksi yang cukup rinci untuk membenarkan pengklasifikasian dari transaksi dalam laporan keuangan secara wajar.

- Terdapat sistem informasi yang mencakup metode-metode dan catatan-catatan untuk transaksi pemberian pinjaman yang mengungkapkan pemberian pinjaman yang berhubungan dengan laporan keuangan secara wajar dalam Koperasi.

- Terdapat sistem informasi yang mencakup metode-metode dan catatan-catatan dalam hal posting dan pengikhtisaran yang benar atas transaksi-transaksi pemberian pinjaman.

Pemantauan merupakan proses penilaian struktur pengendalian internal sepanjang waktu. Dalam hal ini pemantauan yang dilakukan oleh Koperasi Pembangunan Usaha Sumbar (KOPUS) telah efektif. Hal ini ditandai dengan adanya

Pimpinan/

Manajer selalu memantau perkembangan saldo piutang usaha per debitur setiap saat dan Badan Pengawas selalu memberikan perhatian lebih terhadap piutang usaha dalam kegiatan audit.

Berikut ini adalah skor kuesioner pengendalian intern piutang usaha pada Koperasi Pembangunan Usaha Sumbar (KOPUS).

Tabel 4.1

Skor Kuesioner Pengendalian Intern Piutang Usaha

\begin{tabular}{|c|c|c|c|}
\hline No. & $\begin{array}{c}\text { Kelas } \\
\text { Interval }\end{array}$ & Nilai & Keterangan \\
\hline 1. & $0-20$ & TE & Tidak Efektif \\
\hline 2. & $21-40$ & KE & $\begin{array}{c}\text { Kurang } \\
\text { Efektif }\end{array}$ \\
\hline 3. & $41-60$ & $\mathrm{CE}$ & $\begin{array}{c}\text { Cukup } \\
\text { Efektif }\end{array}$ \\
\hline 4. & $61-80$ & $\mathrm{E}$ & Efektif \\
\hline 5. & $81-100$ & $\mathrm{SE}$ & $\begin{array}{c}\text { Sangat } \\
\text { Efektif }\end{array}$ \\
\hline
\end{tabular}

(Kuesioner Pengendalian Intern

Piutang Usaha Terlampir)

Melalui tabel diatas, maka efektivitas pengendalian intern piutang usaha dapat dihitung sebagai berikut :

Jumlah Jawaban Kuesioner

Total Pertanyaan

$\frac{(1 \times 40)+(28 \times 80)}{29}$

: $2.280 / 29=\mathbf{7 8 . 6 2}$ (berada dalam kelas 61-80 $=\mathrm{E}$ )

: Efektif

Dari perhitungan diatas diperoleh hasil 78.62, berarti pengendalian intern piutang usaha pada Koperasi Pembangunan Usaha Sumbar (KOPUS) sudah efektif.

\section{KESIMPULAN DAN SARAN}




\section{Kesimpulan}

Berikut ini beberapa hal yang dapat disimpulkan dari hasil penelitian guna menjawab permasalahan yang dihadapi.

1. Pengendalian Intern merupakan kontrol internal yang berisi rencana organisasi dan semua metode yang terkoordinasi dan pengukuranpengukuran yang diterapkan diperusahaan untuk mengamankan aktiva, memeriksa akurasi dan kehandalan data akuntansi, meningkatkan efisiensi operasional, dan mendorong ketaatan terhadap kebijakan manajerial yang telah ditetapkan.

2. Koperasi Pembangunan Usaha Sumbar (KOPUS) merupakan salah satu Koperasi Simpan Pinjam berbadan hukum yang ada di Kota Padang yang menyelenggarakan usaha simpan pinjam dan usaha lainnya.

3. Secara keseluruhan, pengendalian intern terhadap piutang usaha pada Koperasi Pembangunan Usaha Sumbar (KOPUS) berjalan efektif, dimana manajemen perusahaan sudah menerapkan konsep dasar dan prinsip-prinsip pengendalian intern.

4. Lingkungan pengendalian terhadap piutang usaha pada Koperasi Pembangunan Usaha Sumbar (KOPUS) sudah berjalan dengan efektif, hal ini ditandai salah satunya dengan penerapan SOP (standard operating procedures) pada bagian Kolektor.

5. Penentuan resiko dan aktivitas pengendalian terhadap piutang usaha pada Koperasi Pembangunan Usaha Sumbar (KOPUS) sudah efektif karena fungsi yang melakukan penagihan piutang diasuransikan oleh perusahaan, adanya pemisahan tugas, dan otorisasi dari pejabat yang berwenang.

6. Informasi dan komunikasi mengenai piutang usaha telah diterapkan dengan efektif, baik informasi yang disampaikan oleh manajemen kepada bawahannya maupun informasi yang berasal dari karyawan kepada manajemen.

7. pemantauan terhadap piutang usaha telah berjalan baik dan efektif, baik pengawasan yang dilakukan oleh manajer maupun oleh badan pengawas terhadap piutang usaha.

\section{Saran}

Berikut beberapa saran yang dapat dikemukakan oleh penulis antara lain :

1. Untuk menghindari terjadinya perangkapan tugas dimana setiap bagian bertanggung jawab atas bagiannya masing-masing. Perlu adanya penambahan jumlah karyawan Koperasi Pembangunan Usaha Sumbar.

2. Pihak koperasi belum ada membuat suatu kebijakan yang baku dan tertulis terhadap ketentuanketentuan yang berlaku di Koperasi, hanya bersifat lisan saja. Untuk itu ke depannya perlu dirumuskan kebijakan tertulis siapa saja yang berwenang menyetujui pinjaman, misalnya ; dibawah < Rp. 1 Milyar wewenang manajer, diatas > Rp 1 Milyar persetujuan manajer dan salah satu pengurus.

\section{DAFTAR PUSTAKA}

Arens, Alvin A, dkk, 2001. Auditing Suatu Pendekatan Terpadu, Cetakan Keenam, Buku Satu, Edisi Indonesia, Terjemahan Ilham Tjakrakusuma, Penerbit : Erlangga, Jakarta.

Arthur W. Holmes, David C. Burns, 2002. Auditing Norma dan Prosedur, Edisi Keempatbelas, Terjemahan 
Bajuri, Penerbit : Erlangga, Jakrta.

Daryanto, S.S, 2000. Kamus lengkap Bahasa Indonesia, Penerbit : Apollo, Surabaya. Gondodiyoto Sanyoto, 2007. Audit Sistem Informasi + Pendekatan CobIT, Edisi Revisi, Penerbit : Mitra Wacana Media, Jakarta.

Gunawan Adisaputro, 2003. Anggaran Perusahaan, Cetakan Kesembilan, Jilid Dua, Edisi Pertama, Penerbit : BPFE, Yogyakarta.

Haryono Al, Sidiq, Krismiaji, 1998. Praktik Auditing, Cetakan Keempat, Buku Satu, Penerbit : PPAA YKPN, Yogyakarta.

Ikatan Akuntan Indonesia, 2004. Standar Akuntansi Keuangan, Penerbit : Salemba Empat, Jakarta.

Jurusan Akuntansi, Fakultas Ekonomi Universitas Sumatera Utara, Jurusan Akuntansi, 2008. Buku Petunjuk Teknis Penulisan Proposal Penelitian dan Penulisan Skripsi, Medan.

Manahan, 2005. Manajemen Keuangan, Konseptual, Problem dan Studi Kasus, Cetakan Keduabelas, Penerbit : Ghalia Indonesia, Bandung.

Messier, Glover, Prawitt. 2005. Auditing Services \& Assurance a Systematic Approach, Buku Dua, Edisi Keempat, Penerbit : Salemba Empat, Jakarta.

Mulyadi, 2001. Sistem Akuntansi, Cetakan Ketiga, Edisi Ketiga, Penerbit : Salemba Empat, Jakarta.
Niswonger, Warren, Reeves, 2001. Prinsip-prinsip Akuntansi, Edisi Keduapuluh, Jilid Satu, Penerbit : Erlangga, Jakarta.

Riyanto Bambang, 2001. Dasardasar Pembelanjaan

Perusahaan, Edisi

Keempat, Penerbit : Salemba Empat, Jakarta.

Robert N. Antony, Vijay Govindarajan, 2005. Management Control System, Buku Satu, Penerbit : Salemba Empat, Jakarta.

Sawyer, Dittenhofer, S Cheiner, 2005. Internal Auditing, Buku Satu, Edisi Kelima, Penerbit : Salemba Empat, Jakarta.

Sekaran Uma, 2006. Metodologi Penelitian Untuk Bisnis, Buku Satu, Edisi Keempat, Penerbit : Salemba Empat, Jakarta.

Soemarso S.R., 2003. Akuntansi Suatu Pengantar, Buku Dua, Edisi Kelima, Penerbit : Salemba Empat, Jakarta.

Stice, Stice, Skousen, 2004. Intermediate Accounting, Buku Satu, Edisi Kelima belas, Penerbit : Salemba Empat, Jakarta.

Tisnawati Sule Ernic, Kurniawan Saefullah, 2006. Pengantar Manajemen, Cetakan Kedua, Edisi Pertama, Penerbit : Kencana, Jakarta. Zubeirsyah, Nurhayati Lubis, 2008. Bahasa Indonesia dan Teknik Penyusunan Karangan Ilmiah, Penerbit : Universitas Sumatera Utara, Medan. 